\title{
Authentic Assessment for Speaking Skills: Problem and Solution for English Secondary School Teachers in Indonesia
}

\section{Zaim}

Prof., at English Language Education, Universitas Negeri Padang, Indonesia, mzaim@fbs.unp.ac.id

\section{Refnaldi}

English Language Education, Universitas Negeri Padang, Indonesia, refnaldi@yahoo.com

\section{Safnil Arsyad}

Prof. at English Department, Universitas Bengkulu, Indonesia, safnilarsyad@ gmail.com

Although authentic assessment is obligatory in the 2013 Curriculum in Indonesia, teachers find many practical problems in English classrooms, especially when assessing students' speaking ability. This research aims to reveal the teachers' problems on authentic assessment to evaluate the English speaking skills of junior high school students, to find out teachers' need on the authentic assessment of speaking skill, and to develop a model of authentic assessment suitable with teachers' need and characteristics of the learners. This study was a research and development study using the ADDIE Model. The data of the study were obtained from teachers' responses on the questionnaires regarding the students' needs on the use of authentic assessment for English speaking skills. The finding shows (1) the problems faced by teachers regarding the assessment of specific language functions, (2) teachers' needs on the authentic assessment regarding the language functions, activities, and scoring rubrics for speaking skills, (3) the model of authentic assessment suitable with teachers' need related to language function, activities, and scoring rubrics The appropriate need analysis can be used effectively in developing authentic assessment for speaking skills.

Keywords: need analysis, speaking skills, teaching English, language function, EFL

\section{INTRODUCTION}

The 2013 Curriculum in Indonesian education required teachers to implement authentic assessment as the method of assessing students' competence (Kemdikbud, 2013; Sofiana, Mubarok, \& Yuliasri, 2019); however the implementation of this type of

Citation: Zaim, M., Refnaldi, \& Arsyad, S. (2020). Authentic Assessment for Speaking Skills: Problem and Solution for English Secondary School Teachers in Indonesia. International Journal of Instruction, 13(3), 587-604. https://doi.org/10.29333/iji.2020.13340a 
assessment is quite difficult in class (Nurgiantoro \& Suyata, 2009; Zaim \& Amri, 2012; Zaim, 2013; Zaim \& Refnaldi 2016; Rukmini \& Saputri, 2017). Teachers do not have enough knowledge to assess language skills authentically because they are accustomed to pencil and paper test method to assess the students' achievement. The pencil and paper test method can be applied to assess grammar, reading skill, and listening skill, but not suitable to assess speaking skill and writing skill. In addition, in the 2013 Curriculum, students are encouraged to have interpersonal skills, the ability to think critically (Kurniasih \& Sani, 2014), right attitude, knowledge, and psychomotor skills which are relevant to the need of life (Lazim, 2013; Zaim, 2017) that cannot be assessed by pencil and paper test only. Therefore, authentic assessment is needed to be applied in class.

An authentic assessment is a process of gathering information by teachers about students' progress and learning achievement, which is done through various techniques. This kind of assessment can express, to prove, or to show precisely what the learning objectives have been completely overcome and achieved. O'Malley \& Pierce (1996) state that "Authentic assessment is an evaluation process that involves multiple forms of performance measurement reflecting the student's learning achievement, motivation, and attitudes on instructionally-relevant activities." Besides, Taufina (2009) mentions that authentic assessment is a process to describe the changes in students after the learning process. Thus, the assessment is no longer merely assessing the achievement of learning objectives. However, it is an attempt to obtain a variety of information regularly, a continuous and thorough process, and students' learning outcomes.

Among the four language skills (speaking, listening, reading, and writing), speaking is considered to be the most challenging skill (Richard, 2008; Navidinia, Mobaraki, \& Malekzadeh, 2019) to assess by junior high school teachers (Zaim, 2013; Rahmawati \& Ertin, 2014; Razali \& Isra, 2016). Teachers lack knowledge on how to assess the speaking ability of the students and reluctant to test verbal ability (Knight, 1992). Speaking should be directly assessed when the speakers interact orally in the tasks given. Some indicators of assessing speaking skills should be examined in grading the students' speaking ability. As a result, teachers do not follow the procedures to assess students' speaking ability correctly. Therefore, teachers' needs and problems in implementing authentic assessment for speaking skills at the junior high school should be found out, and the solution should be proposed by creating the model of authentic assessment for speaking skills suitable for teachers' needs. For assessing speaking skills, authentic assessment is the precise method to measure students' ability to communicate in the language being learned orally. It demonstrates students' learning achievement through their completion and affords opportunities to apply knowledge, skills, and attitude in a practical context (Williams, 2016; Ojung's \& Allida, 2017).

An authentic assessment in language learning is a form of assessment that can improve the quality of assessment of language learning (Taufina, 2009) because it can measure the abilities and skills of students in learning precisely (Zaim \& Refnaldi, 2017). For students, with authentic assessments, their true abilities can be well measured. For teachers, various forms of authentic assessment are expected to facilitate measuring exact students' language abilities and skills (Bachman, 1990). 
An authentic assessment always allows students to demonstrate their knowledge and skill well. Authentic assessment, according to Moon (2005), has the following characteristics: (1) focus on the material that is essential, big ideas or the skill-specific skills, (2) an in-depth assessment, (3) easy to do in the classroom or in the school environment, (4) emphasis on product quality or performance of the single answer, (5) can develop students' strength and learning mastery, (6) have criteria that are known, understood and negotiated by students and teachers before the assessment begins, (7) provides lots of ways students can demonstrate that it has met the established criteria, and (8) scoring assessment based on the essence of the task. Furthermore, Moon (2005) states that his research has shown that the development of the authentic assessment in schools has received a positive response both by teachers and students. More authentic assessment results can provide information about consistent learning outcomes compared with traditional evaluation techniques (paper and pencil test).

Haryono (2009) suggests that there are four general principles of authentic assessment. (1) The assessment process should be an integral part of the learning process, not a separate part of the learning process (a part of, not apart from instruction). (2) The assessment should reflect the real-world problems, not school work-kind of problems. (3) The assessment must use a variety of sizes, methods, and criteria following the characteristics and essence of the learning experience. (4) The assessment must be holistic, covering all aspects of the learning objectives (cognitive, affective, and sensory-motor). Furthermore, Imran (2012) reveals some characteristics of authentic assessment. He stated that the system of authentic assessment is undertaken to (1) measure the knowledge and skills of students, (2) assess performances, (3) use the tasks that are relevant and contextual, (4) assess a variety of ways and from a variety of sources, (5) require the application of knowledge and skills, and (6) measure both process and product. Thus, authentic assessment is more comprehensive than standardized tests.

To implement an authentic assessment, there are some steps that teachers need to consider. Haryono (2009) suggests that the development of an authentic assessment system can be done through several steps. (1) Assessing competency standards. This standard has been listed on the curriculum that describes the minimal ability to be possessed by graduates in each subject. This standard has significant implications for the planning, implementation, and management assessment. (2) Reviewing the basic competencies. Basic competence is the minimum ability of students needed in the given subject. (3) Developing the syllabus which includes indicators, learning experiences, learning materials, a domain of valuation and appraisal activity schedules in one semester. These activities would be better if it is done in conjunction with the development of the learning materials. (4) Implementing the process using a variety of evaluation techniques as it has been planned and the implementation of the schedule that has been informed by the students. (5) Recording, processing, following-up, and reporting. All the assessment results strived always to be well documented. A follow-up of the results of the assessment report can be either enrichment or remedial.

Several studies can be found in the literature regarding the use of authentic assessment in the classrooms. Irwana (2006), for example, found that the assessment in language 
learning is focused on aspects of language, such as grammar and vocabulary, so that more students master the use of the language rather than fluent in using the language in oral communication (speaking skill). In her research on the application of authentic assessment in junior high school, she stated that there are four forms of assessment used in language learning. They are the performance assessment, product assessment, portfolio assessment, and assessment tests. The problem faced by teachers in implementing authentic assessment is the lack of experience the teachers have, and it takes a lot of time and effort to administer student grades and subjectivity in giving the final mark. To avoid subjectivity in giving the mark, Sahyoni \& Zaim (2017) propose a model of rubrics which have the description of the level of achievement, so that the teacher can judge in which level of ability the students are now in the assessment given.

Nurgiantoro \& Suyata (2009) suggested that, in general, teachers do not understand how to implement authentic assessment in language learning in the classroom, even though the assessment is the one recommended in the School-Based Curriculum. Therefore, teachers expect the guidebooks that contain the concept of authentic assessment to measure proficiency, easy to follow, and there are examples of the assessment and measures. Furthermore, Zaim \& Amri (2012) and Zaim (2013), in their study on the implementation of authentic assessment in junior high school, found that teachers of English have difficulty in making a proper assessment rubric to assess the oral language skills. In line with the findings above, Whitelock \& Cross (2012), in their research about the use of authentic assessment in distance learning academics, found that authentic assessment is problematic to collate features within assessment tasks.

The above studies imply that English teachers have practical problems in implementing authentic assessment in the classrooms, especially when assessing their students speaking ability; however, none of the studies discussed in detail the problems faced by the teachers have suggested a useful and practical solution to the problem. Similarly, Nasab (2015) suggests that teachers need the model of authentic assessments suitable to their needs (Finch, 2002; Wu, 2014; Zaim, 2017), especially for assessing speaking skills. This is the rationale for this study; that is to investigate various practical problems experienced by teachers in implementing authentic assessment in the classrooms and suggesting a useful and practical solution to the problem. The following questions are addressed in this study as a guideline:

1) What kinds of problem are faced by English teachers at secondary schools in assessing their student's speaking ability authentically in the classroom?

2) What communicative functions need to be assessed authentically in the classroom?

3) What model is suitable for English teachers to authentically assess student's speaking ability in the classroom?

\section{METHOD}

\section{Research Design}

This research was a research and development design using the first three steps of the ADDIE Model (Analyze, Design, Develop, Implement, and Evaluation). They were Analyze, Design, and Develop, the three essential steps to be done in the ADDIE model before teachers can implement and evaluate the authentic assessment of speaking skills 
in class. The analyzing step involved the analysis of teacher's problems and needs. Then, the findings on the problem and the need analysis were used to design the model of authentic assessment for speaking skills. Finally, the design was developed into a model of authentic assessment of speaking skills for junior high school students. The result of development must be implemented and evaluated before the model is used widely by teachers at junior high school. However, the result of the implementation and evaluation of the use of the model of authentic assessment of speaking skills will be explained in a different report.

\section{Respondents}

The respondents of this research were 120 secondary school English as a foreign language teacher from West Sumatra Province, Indonesia, who have implemented authentic assessment in their class. They had taught the English subject for at least five years. Of the 120 respondents, $70 \%$ were females, and $30 \%$ were males. Their ages are between 30-58 years old. The data of the research were obtained from their responses to the questionnaire given regarding their problems and needs on the use of authentic assessment for assessing English speaking skills at junior high school.

\section{Instruments}

The instrument employed in this research was a questionnaire which was used to find out teachers' problems and needs on authentic assessment for speaking skill at junior high school. The questionnaire was developed based on a small-scale survey of junior high school teachers' needs to ensure the relevance and meaningfulness of the gap between the problems and the level of needs dealing with three main factors in assessing speaking skills, namely communicative functions, various forms of assessment activities, and various topics of speaking assessment (O’Malley \& Pierce, 1996; Brown \& Abeywickrama, 2010). There were 44 statement items used in the questionnaire. Thirteen items were related to communicative functions, 13 items dealt with forms of assessment activities, and 18 items were about types of the topic used in assessing speaking.

The questionnaire using a Likert scale (Warmbrod, 2014) with five options ranging from $1=$ Never, $2=$ Seldom, $3=$ Sometimes, $4=$ Often, and 5=Very Often, were used to collect the data related to teachers' problems in assessing communicative function, forms of assessment, and topics of assessment. The questionnaire using four options Likert scale ranging from $1=$ Not Important, $2=$ Less Important, $3=$ Important, and 4=Very Important were used to get the data related to the level of teachers' needs. For the validity and reliability of the instrument, the Cronbach's Alpha of the instrument is 0.78, which proves that it is highly reliable and valid as the instrument for collecting the data.

\section{Data Analysis}

Quantitative analyses of the data were conducted chronologically, beginning with analyzing the problems and then analyzing the need of the teachers. First of all, for analysis of the responses from the 120 questionnaires taken from the participants, a frequency distribution method was used. Each option in the questionnaire related to teachers' problems was scored 1 for Never, 2 for Seldom, 3 for Sometimes, 4 for Often, 
and 5 for Very Often. Then, each option in the questionnaire related to the level of teachers' need was scored 1 for Not Important, 2 for Less Important, 3 for Important, and 4 for Very Important. The score of each participant was counted, and the score of each item in the questionnaire was also counted. The mean score of each item was categorized into Very Low (VL), Low (L), Mid (M), High (H), or Very High (VH). For Likert scale with five options, the interval scores to decide the level category are as follows: $1.00-1.50=$ Very Low, 1.51-2.50 = Low, 2.51-3.50 = Mid, 3.51-4.50 = High, and 451-5.00 = Very High. For Likert scale with four options, the interval score to decide the level category are as follows: $1.00-1.50=$ Very Low, 1.51-2.25 = Low, 2.262.75 = Mid, 2.76-3.50 = High, and 3.50-4.00 = Very High .

\section{FINDINGS AND DISCUSSION}

The following explanation is the analysis and findings of the three main steps in developing the model of authentic assessment and also to answer the three research questions. The analysis began with revealing the problems faced by teachers regarding the assessment of specific communicative functions, forms of assessment, and topics of assessment. Then, need analysis was done to identify teachers' needs on authentic assessment related to communicative functions, forms, topics, and scoring rubrics. Finally, the model of authentic assessment suitable with teachers' needs related to specific communicative functions, forms of assessment, topics of assessment, and scoring rubrics were developed.

\section{Teachers' problems in implementing authentic assessment}

The first aspect is the problem faced by teachers in assessment concerning certain communicative functions of language. To explore the problems faced by teachers in assessing the communicative functions of language, 13 items were used as a tool to reveal teachers' responses. The following table illustrates the teachers' responses to each item.

\section{Table 1}

Problems Faced by Teachers in Assessing the Communicative Function

\begin{tabular}{|c|c|c|c|c|c|c|c|c|c|}
\hline \multirow{2}{*}{\multicolumn{2}{|c|}{ No Items }} & \multicolumn{8}{|c|}{ The score of teachers' responses } \\
\hline & & $\mathrm{N}$ & $\mathrm{S}$ & ST & $\mathrm{O}$ & $\mathrm{VO}$ & $\mathrm{T}$ & A & $\mathrm{C}$ \\
\hline 1 & Asking students to say greetings and to respond to the greetings & 30 & 54 & 120 & 60 & 40 & 304 & 2.53 & $\mathrm{~L}$ \\
\hline 2 & Asking students to say partings and to respond partings & 50 & 60 & 81 & 36 & 20 & 247 & 2.06 & $\mathrm{~L}$ \\
\hline 3 & Asking students to say thanking and to respond thanking & 40 & 100 & 39 & 32 & 45 & 256 & 2.13 & $\mathrm{~L}$ \\
\hline 4 & Asking students to apologize and to respond an apology & 15 & 48 & 90 & 144 & 75 & 372 & 3.10 & M \\
\hline 5 & Asking students to introduce him/herself & 18 & 54 & 117 & 96 & 60 & 345 & 2.88 & $\mathrm{M}$ \\
\hline 6 & Asking students to tell about his/her family & 9 & 42 & 90 & 180 & 75 & 396 & 3.30 & $\mathrm{M}$ \\
\hline 7 & Asking students to introduce his/her classmates & 3 & 54 & 117 & 156 & 60 & 390 & 3.25 & M \\
\hline 8 & Asking students to tell the time & 5 & 60 & 105 & 168 & 40 & 378 & 3.15 & $\mathrm{M}$ \\
\hline 9 & Asking students to describe things & 3 & 54 & 117 & 160 & 55 & 389 & 3.24 & $\mathrm{M}$ \\
\hline & Asking students to describe places & 0 & 34 & 99 & 200 & 100 & 433 & 3.61 & $\mathrm{H}$ \\
\hline & Asking students to describe people & 4 & 40 & 117 & 204 & 30 & 395 & 3.29 & $\mathrm{M}$ \\
\hline 12 & Asking students to tell the label & 0 & 0 & 162 & 216 & 60 & 438 & 3.65 & $\mathrm{H}$ \\
\hline & Asking students to give simple instructions & 0 & 30 & 225 & 72 & 60 & 387 & 3.23 & $\mathrm{M}$ \\
\hline & Mean & & & & & & & 3.02 & $\mathrm{M}$ \\
\hline
\end{tabular}

Notes: $\mathrm{N}=$ Never, $\mathrm{S}=$ Seldom, $\mathrm{ST}=$ Sometimes, $\mathrm{O}=$ Often, $\mathrm{VO}=$ Very Often, VL = Very Low, $\mathrm{L}=$ Low, $\mathrm{M}=$ Mid, $\mathrm{H}=$ High, $\mathrm{VH}=$ Very High, $\mathrm{T}=$ Total, $\mathrm{A}=$ Average, $\mathrm{C}=$ Category 
Table 1 above shows that, in general, the problems faced by teachers regarding the assessment of specific communicative functions are at the Mid-level (M). In specific, the table shows that there are two items in the high $(\mathrm{H})$ category, i.e., asking students to describe places (with the mean score of 3.61) and to ask students to tell the label (with the mean score of 3,65). Nine communicative functions are in the mid (M) category, and three communicative functions are in the low (L) category.

The things that should be considered in the development of a model of authentic assessment are the communicative functions that are in the High and Mid categories. Two communicative functions in the High category are asking students to describe a place and asking students to tell the label. The communicative functions in the Mid category are asking students to say the apology and respond to the apology of others, asking students to introduce themselves, asking students to tell about the family, asking students to introduce classmates, asking students describe time, asking students to describe an object, asking students to describe a person/animal, and asking students to give simple instructions.

Table 1 above reveals that from 13 communicative functions of speaking skills, ten items are considered to be difficult to assess authentically. Those items related to a very beginning level of oral communication such as introducing him/herself, his/her family, and his/her friend, telling about his/her family, time, and label; describing things/place/people, and giving simple instruction.

The second component is teachers' problems of forms of assessment. To explore the problems faced by teachers in using forms of assessment, 13 statements are used to collect the data. The following table illustrates the teachers' responses to each statement.

Table 2

Problems of using Various forms of Assessment

\begin{tabular}{|c|c|c|c|c|c|c|c|c|c|}
\hline \multirow[t]{2}{*}{ No } & \multirow[t]{2}{*}{ Assessment Form } & \multicolumn{5}{|c|}{ The score of teachers' responses } & \multirow[b]{2}{*}{$\mathrm{T}$} & \multirow[b]{2}{*}{ A } & \multirow[b]{2}{*}{$\mathrm{C}$} \\
\hline & & $\mathrm{N}$ & $\mathrm{S}$ & ST & $\mathrm{O}$ & $\mathrm{VO}$ & & & \\
\hline 1 & Oral interview & 40 & 62 & 135 & 8 & 10 & 255 & 2.13 & $\mathrm{~L}$ \\
\hline 2 & Picture-cued Description & 15 & 80 & 81 & 132 & 25 & 333 & 2.78 & $\mathrm{M}$ \\
\hline 3 & Information Gap & 0 & 18 & 45 & 240 & 180 & 483 & 4.03 & $\mathrm{H}$ \\
\hline 4 & Story/Text Retelling & 30 & 72 & 90 & 96 & 0 & 288 & 2.40 & $\mathrm{~L}$ \\
\hline 5 & Roleplays & 0 & 30 & 90 & 220 & 100 & 440 & 3.67 & $\mathrm{H}$ \\
\hline 6 & Oral Reports & 0 & 54 & 108 & 180 & 60 & 402 & 3.35 & $\mathrm{M}$ \\
\hline 7 & Debates & 0 & 30 & 72 & 204 & 150 & 456 & 3.80 & $\mathrm{H}$ \\
\hline 8 & Speech & 0 & 48 & 63 & 252 & 60 & 423 & 3.53 & $\mathrm{H}$ \\
\hline 9 & Act out & 0 & 2 & 72 & 300 & 100 & 474 & 3.95 & $\mathrm{H}$ \\
\hline 10 & Short presentation & 0 & 30 & 78 & 276 & 50 & 434 & 3.62 & $\mathrm{H}$ \\
\hline 11 & Short discussion & 0 & 0 & 63 & 300 & 120 & 483 & 4.03 & $\mathrm{H}$ \\
\hline 12 & Guessing games & 0 & 18 & 108 & 252 & 60 & 438 & 3.65 & $\mathrm{H}$ \\
\hline \multirow[t]{2}{*}{13} & Pair dialogue & 5 & 30 & 135 & 200 & 25 & 395 & 3.29 & $\mathrm{M}$ \\
\hline & Mean & & & & & & & 3.40 & $\mathrm{H}$ \\
\hline
\end{tabular}

Notes: $\mathrm{N}=$ Never, $\mathrm{S}=$ Seldom, $\mathrm{ST}=$ Sometimes, $\mathrm{O}=$ Often, $\mathrm{VO}=$ Very Often, $\mathrm{VL}=$ Very Low, $\mathrm{L}=$ Low, $\mathrm{M}=\mathrm{Mid}, \mathrm{H}=$ High, $\mathrm{VH}=$ Very High, $\mathrm{T}=$ Total, $\mathrm{A}=$ Average, $\mathrm{C}=$ Level Category

Table 2 above shows that in general, the frequency of the problems faced by teachers concerning forms of assessment is at the High level. The above table also shows that in 
detail, there are only two forms of assessment the Low category (L), i.e., oral interview and story/text retelling, and three forms of assessment in the Mid category, i.e., picturecued description, oral reports, and pair dialogue. Eight forms of assessment are in the High category. Things that should be considered in the development of a model of authentic assessment are forms of assessment that are in the High category, namely information gap, roleplays, oral reports, debates, speech, act out, a short presentation, short discussion, guessing games, and pair dialogue.

Table 2 above reveals that from 13 forms of assessment, eight items are considered difficult to assess authentically. This means that teachers have not yet able to assess most of the assessment forms required in the curriculum to be assessed authentically.

The third problem deals with the topic of assessment. To explore the problems faced by teachers in using topics of assessment, 18 statements are used to collect the data. The following table illustrates the teachers' responses to each statement.

Table 3

Teachers' Problems with Types of Topic to Assess

\begin{tabular}{llllllllll}
\hline \multirow{2}{*}{ No } & & \multicolumn{2}{l}{ Teachers' score } & & & & \\
\cline { 2 - 9 } & Assessment Topics & $\mathrm{N}$ & $\mathrm{S}$ & $\mathrm{ST}$ & $\mathrm{O}$ & $\mathrm{VO}$ & $\mathrm{T}$ & $\mathrm{A}$ & $\mathrm{C}$ \\
\hline 1 & Self & 63 & 54 & 90 & 0 & 0 & 207 & 1.73 & $\mathrm{VL}$ \\
\hline 2 & Classmates & 54 & 30 & 117 & 48 & 0 & 249 & 2.08 & $\mathrm{~L}$ \\
\hline 3 & Family & 25 & 120 & 24 & 60 & 60 & 289 & 2.41 & $\mathrm{~L}$ \\
\hline 4 & School & 20 & 40 & 81 & 128 & 105 & 374 & 3.12 & $\mathrm{M}$ \\
\hline 5 & Things & 6 & 36 & 108 & 168 & 90 & 408 & 3.40 & $\mathrm{M}$ \\
\hline 6 & Animal & 4 & 24 & 84 & 256 & 60 & 428 & 3.57 & $\mathrm{H}$ \\
\hline 7 & Fruits & 0 & 0 & 135 & 204 & 120 & 459 & 3.83 & $\mathrm{H}$ \\
\hline 8 & Flowers & 6 & 54 & 153 & 144 & 0 & 357 & 2.98 & $\mathrm{M}$ \\
\hline 9 & Clothes & 6 & 90 & 144 & 84 & 0 & 324 & 2.70 & $\mathrm{M}$ \\
\hline 10 & Historical places & 9 & 74 & 117 & 108 & 40 & 348 & 2.90 & $\mathrm{M}$ \\
\hline 11 & Tourist resorts & 10 & 42 & 144 & 120 & 55 & 371 & 3.09 & $\mathrm{M}$ \\
\hline 12 & Famous people & 10 & 60 & 120 & 132 & 35 & 357 & 2.98 & $\mathrm{M}$ \\
\hline 13 & Famous & & & & & & & & \\
& actor/actress & 5 & 8 & 63 & 336 & 30 & 442 & 3.68 & $\mathrm{H}$ \\
\hline 14 & Recipe & 8 & 18 & 54 & 280 & 75 & 435 & 3.63 & $\mathrm{H}$ \\
\hline 15 & Manuals & 4 & 20 & 87 & 236 & 90 & 437 & 3.64 & $\mathrm{H}$ \\
\hline 16 & Advertisement & 0 & 40 & 75 & 120 & 225 & 460 & 3.83 & $\mathrm{H}$ \\
\hline 17 & Announcement & 9 & 30 & 69 & 148 & 180 & 436 & 3.63 & $\mathrm{H}$ \\
\hline 18 & Shopping & 0 & 0 & 108 & 300 & 45 & 453 & 3.78 & $\mathrm{H}$ \\
\hline & Mean & & & & & & & 3.16 & $\mathrm{M}$ \\
\hline
\end{tabular}

Notes: $\mathrm{N}=$ Never, $\mathrm{S}=$ Seldom, $\mathrm{ST}=$ Sometimes, $\mathrm{O}=$ Often, $\mathrm{VO}=$ Very Often, $\mathrm{VL}=$ Very Low, $\mathrm{L}=$ Low, $\mathrm{M}=$ Medium, $\mathrm{H}=$ High, $\mathrm{VH}=$ Very High, $\mathrm{T}=$ Total, $\mathrm{A}=$ Average, $\mathrm{C}=$ Level Category

Table 3 above reveals that the problems of using various topics of assessment vary. Of the 18 statements of the topics, none of the existing topics are in the category of Very High. There are eight topics in the High category, seven topics in the Mid category, two topics in the Low category, and one topic in the Very Low category. The topics that need attention in developing authentic assessment are the ones in the High category. They are animals, fruits, a famous artist, recipes, manuals, advertisements, announcements, and shopping. 
Based on the analysis, as seen in table 1 to 3 above, the findings indicated that teachers still have problems in assessing communicative functions, forms of assessment, and topics to assess their speaking skills. The problems faced by English teachers regarding the assessment of certain communicative functions are mainly about assessing students' ability to express themselves in daily informal communication practices in the classroom. This finding is in line with that of Nurgiantoro \& Suyata (2009) who found that teachers often do not know how to assess and therefore do not carry out an authentic assessment in the classroom when students use English for personal communication with other students or teachers although this is demanded in the curriculum. According to Nurgiantoro and Suyata, this is probably because there is no simple and practical instrument for the teachers to use in order to assess students' speaking proficiency in the classroom.

These findings are also in line with Razali \& Isra (2016) and Ojung'a \& Allida who said that the appropriateness of assessment activity for certain language functions and the format of assessment criteria that will be used are still difficult to decide by most teachers in order to well implement of authentic assessment. Teachers should conduct the authentic assessment of speaking in the right way by understanding communicative functions, a form of assessment, and topics to assess the speaking skills relevant to the level of ability of the students to be assessed.

\section{Teachers' needs on the authentic assessment}

Teachers' needs on the authentic assessment regarding the communicative functions, forms of assessment, topic types, and scoring rubrics were revealed based on the questionnaire distributed to 120 English teachers of junior high schools. Teachers' needs can be used to inform policy-makers in developing a relevant program for teachers $(\mathrm{Wu}$, 2014). The result of teachers' need analysis on the authentic assessment can be seen in the following explanation.

Communicative Function. The level of teachers' needs on speaking authentic assessment regarding the communicative functions was revealed by using 13 statements. Table 4 below illustrates the scores of teachers' responses to each statement. 
Table 4

Students' Needs on Communicative Functions

\begin{tabular}{|c|c|c|c|c|c|c|c|c|}
\hline \multirow[b]{2}{*}{ No } & \multirow[b]{2}{*}{ Statement } & \multicolumn{7}{|c|}{ Response } \\
\hline & & $\mathrm{NI}$ & LI & I & VI & $\mathrm{T}$ & $\mathrm{A}$ & $\mathrm{C}$ \\
\hline 1 & $\begin{array}{l}\text { Asking students to say greetings } \\
\text { and to respond to the greetings }\end{array}$ & 15 & 72 & 144 & 84 & 315 & 2.63 & M \\
\hline 2 & $\begin{array}{l}\text { Asking students to say partings and } \\
\text { to respond partings }\end{array}$ & 18 & 48 & 153 & 108 & 327 & 2.73 & $\mathrm{M}$ \\
\hline 3 & $\begin{array}{l}\text { Asking students to say thanking } \\
\text { and to respond thanking }\end{array}$ & 36 & 90 & 90 & 36 & 252 & 2.10 & $\mathrm{~L}$ \\
\hline 4 & $\begin{array}{l}\text { Asking students to apologize and to } \\
\text { respond an apology }\end{array}$ & 15 & 48 & 135 & 144 & 342 & 2.85 & $\mathrm{H}$ \\
\hline 5 & $\begin{array}{l}\text { Asking students to introduce } \\
\text { him/herself }\end{array}$ & 6 & 54 & 117 & 192 & 369 & 3.08 & $\mathrm{H}$ \\
\hline 6 & $\begin{array}{l}\text { Asking students to tell about his/her } \\
\text { family }\end{array}$ & 15 & 42 & 117 & 180 & 354 & 2.95 & $\mathrm{H}$ \\
\hline 7 & $\begin{array}{l}\text { Asking students to introduce his/her } \\
\text { classmates }\end{array}$ & 15 & 54 & 117 & 156 & 342 & 2.85 & $\mathrm{H}$ \\
\hline 8 & Asking students to tell the time & 7 & 70 & 108 & 168 & 353 & 2.94 & $\mathrm{H}$ \\
\hline 9 & Asking students to describe things & 6 & 36 & 153 & 180 & 375 & 3.13 & $\mathrm{H}$ \\
\hline 10 & Asking students to describe places & 4 & 60 & 105 & 204 & 373 & 3.11 & $\mathrm{H}$ \\
\hline 11 & $\begin{array}{l}\text { Asking students to describe } \\
\text { people/pets }\end{array}$ & 10 & 40 & 117 & 204 & 371 & 3.09 & $\mathrm{H}$ \\
\hline 12 & Asking students to tell the label & 12 & 60 & 162 & 96 & 330 & 2.75 & $\mathrm{M}$ \\
\hline 13 & $\begin{array}{l}\text { Asking students to give simple } \\
\text { instructions }\end{array}$ & 12 & 30 & 225 & 72 & 339 & 2.83 & $\mathrm{H}$ \\
\hline & Mean & & & & & & 2.85 & $\mathrm{H}$ \\
\hline
\end{tabular}

Notes: $\mathrm{NI}=$ Not Important, LI = Less Important, I = Important, VI = Very Important, $\mathrm{VL}=$ Very Low, $\mathrm{L}=$ Low $, \mathrm{M}=\mathrm{Mid}, \mathrm{H}=$ High, $\mathrm{VH}=$ Very High, $\mathrm{T}=$ Total, $\mathrm{A}=$ Average, $\mathrm{C}=$ Level Category

The above table shows that the mean score of teachers' need for the assessment of communicative functions is in the High category. Nine communicative functions are in the High $(\mathrm{H})$ category, three communicative functions are in the Mid category, and one communicative function is in the Low (L) category. The communicative functions that need major concern in developing authentic assessment are the ones that are in the High $(\mathrm{H})$ category. The nine communicative functions in High $(\mathrm{H})$ category are asking students to say the apology and respond to the apology of others, asking students to introduce themselves, asking students to tell about the family, asking students to introduce classmates, asking students to tell the time, asking students to describe an object, asking students to describe a place, asking students to describe a person/animal, and asking students to give simple instructions.

The table above reveals that teachers' need is in line with the problems that they faced in assessing speaking skills such as introducing self and others, telling about family, time, and label, and describing things, place, and people.

Forms of Assessment. The teachers' needs on the various forms of authentic assessment for speaking were revealed by using 13 statements. Table 5 below illustrates the score of teachers' responses to each of these statements. 
Table 5

Teachers' Needs on forms of Assessment

\begin{tabular}{lllllllll}
\hline \multirow{2}{*}{ No } & Forms of & \multicolumn{2}{l}{ Response } & \multicolumn{2}{l}{} \\
\cline { 2 - 8 } & Assessment & NI & LI & I & VI & T & A & C \\
\hline 1 & Oral interview & 0 & 60 & 135 & 180 & 375 & 3.13 & $\mathrm{H}$ \\
\hline 2 & $\begin{array}{l}\text { Picture-cued } \\
\text { Description }\end{array}$ & 0 & 0 & 165 & 260 & 425 & 3.54 & VH \\
\hline 3 & Information Gap & 4 & 88 & 180 & 48 & 320 & 2.67 & $\mathrm{M}$ \\
\hline 4 & Story/Text & & & & & & & \\
& Retelling & 0 & 30 & 270 & 60 & 360 & 3.00 & $\mathrm{H}$ \\
\hline 5 & Roleplays & 0 & 0 & 144 & 288 & 432 & 3.60 & $\mathrm{VH}$ \\
\hline 6 & Oral Reports & 0 & 54 & 144 & 180 & 378 & 3.15 & $\mathrm{H}$ \\
\hline 7 & Debates & 30 & 52 & 72 & 160 & 314 & 2.62 & $\mathrm{M}$ \\
\hline 8 & Speech & 24 & 78 & 135 & 48 & 285 & 2.38 & $\mathrm{M}$ \\
\hline 9 & Act out & 0 & 12 & 72 & 360 & 444 & 3.70 & $\mathrm{VH}$ \\
\hline 10 & Short presentation & 0 & 60 & 135 & 180 & 375 & 3.13 & $\mathrm{H}$ \\
\hline 11 & Short discussion & 20 & 90 & 75 & 120 & 305 & 2.54 & $\mathrm{M}$ \\
\hline 12 & Guessing games & 15 & 90 & 123 & 76 & 304 & 2.53 & $\mathrm{M}$ \\
\hline 13 & Pair dialogue & 0 & 0 & 108 & 336 & 444 & 3.70 & $\mathrm{VH}$ \\
\hline & Mean & & & & & & 3.05 & $\mathrm{H}$ \\
\hline
\end{tabular}

Notes: NI = Not Important, LI = Less Important, I = Important, VI = Very Important, $\mathrm{VL}=$ Very, Low, $\mathrm{L}=$ Low, $\mathrm{M}=$ Mid, $\mathrm{H}=$ High, $\mathrm{VH}=$ Very High, $\mathrm{T}=$ Total, $\mathrm{A}=$ Average, $\mathrm{C}=$ Level Category

The above table shows that the level of need for teachers to various forms of authentic assessment activities varies. There are four forms of assessment that are in the category of Very High, namely picture-cued description, roleplay, act out, and pair dialogue. Four forms of assessment are in the category of High, two forms of activity that are in the category of Medium, and five forms of assessment activities are in the category of Mid. The forms of authentic assessment activities that need major concern in developing authentic assessment are the ones in the category of Very High (VH) and High $(\mathrm{H})$, namely picture-cued description, roleplay, act out, pair dialogue, oral interview, story/text retelling, oral report, and a short presentation.

Table 5 above reveals that from 13 forms of assessment, there are only four forms of assessment that are very highly needed by teachers, they are picture description, role play, act out, and pair dialogue. These forms of assessment are the most frequently used by teachers to assess the particular function of language, as stated in the 2013 curriculum.

Types of the topic. The third component of the needs analysis is the types of topics used in the assessment. There are 18 types of topics that were examined in this component. The needs of teachers on various topics of authentic assessment activities for speaking skills can be seen in the following table. 
Table 6

Teachers' Needs on Certain Topics

\begin{tabular}{lllllllll}
\hline \multirow{2}{*}{ No } & Assessment Topics & \multicolumn{2}{l}{ Response } & \multicolumn{2}{l}{} & \\
\cline { 2 - 8 } & & NI & LI & I & VI & T & A & C \\
\hline 1 & Self & 0 & 2 & 168 & 252 & 422 & 3.52 & VH \\
\hline 2 & Classmates & 0 & 16 & 138 & 264 & 418 & 3.48 & VH \\
\hline 3 & Family & 0 & 20 & 87 & 324 & 431 & 3.59 & VH \\
\hline 4 & School & 0 & 24 & 225 & 132 & 381 & 3.18 & $\mathrm{H}$ \\
\hline 5 & Things & 3 & 36 & 270 & 36 & 345 & 2.88 & $\mathrm{H}$ \\
\hline 6 & Animal & 0 & 0 & 153 & 276 & 429 & 3.58 & VH \\
\hline 7 & Fruits & 2 & 68 & 135 & 156 & 361 & 3.01 & $\mathrm{H}$ \\
\hline 8 & Flowers & 0 & 90 & 153 & 96 & 339 & 2.83 & $\mathrm{H}$ \\
\hline 9 & Clothes & 9 & 108 & 99 & 96 & 312 & 2.60 & $\mathrm{M}$ \\
\hline 10 & Historical places & 15 & 78 & 180 & 24 & 297 & 2.48 & $\mathrm{M}$ \\
\hline 11 & Tourist resorts & 0 & 30 & 225 & 120 & 375 & 3.13 & $\mathrm{H}$ \\
\hline 12 & Famous people & 0 & 30 & 252 & 84 & 366 & 3.05 & $\mathrm{H}$ \\
\hline 13 & Famous actor/actress & 0 & 54 & 171 & 144 & 369 & 3.08 & $\mathrm{H}$ \\
\hline 14 & Recipe & 21 & 102 & 108 & 48 & 279 & 2.33 & $\mathrm{M}$ \\
\hline 15 & Manuals & 4 & 18 & 231 & 120 & 373 & 3.11 & $\mathrm{H}$ \\
\hline 16 & Advertisement & 12 & 120 & 90 & 72 & 294 & 2.45 & $\mathrm{M}$ \\
17 & Announcement & 0 & 36 & 252 & 72 & 360 & 3.00 & $\mathrm{H}$ \\
\hline 18 & Shopping & 15 & 48 & 180 & 84 & 327 & 2.73 & $\mathrm{M}$ \\
\hline & Mean & & & & & & 3.00 & $\mathrm{H}$ \\
\hline
\end{tabular}

Notes: $\mathrm{NI}=$ Not Important, LI = Less Important, I = Important, VI = Very Important, $\mathrm{VL}=$ Very Low, $\mathrm{L}=$ Low, $\mathrm{M}=$ Mid, $\mathrm{H}=$ High, $\mathrm{VH}=$ Very High, $\mathrm{T}=$ Total, $\mathrm{A}=$ Average, $\mathrm{C}=$ Level Category

The above table shows that the level of teachers' needs on various topics for authentic assessment activities varies. There are four topics of assessment activities that are in the Very High (VH) category. They are myself, classmates, family, and pets. There are nine topics of assessment activities that are in the High $(\mathrm{H})$ category, five topics in the Mid (M) category, and no topic in Low and Very Low categories. The topics of authentic assessment activities that should be focused on developing authentic assessment are the ones in High and Mid categories. They are self, classmate, family, school, inanimate objects, animals, fruits, flowers, clothes, famous people, a famous artist, manuals, and announcements.

Significant correlation has been found between problems faced by teachers in implementing authentic assessment of speaking skills $(\mathrm{X})$ and teachers' needs on communicative functions, forms of assessment, and topics of assessment $(\mathrm{Y}), \mathrm{t}(\mathrm{df}=42)$ $=4.656, \mathrm{p}<0.05$. So it can be concluded that the teacher's problem significantly correlates with the teacher's need.

\section{The model of authentic assessment suitable with teachers' need}

The model of authentic assessments developed was based on the language functions, the activities, and types of the topics needed by the teachers, as mentioned above. The 
authentic assessments should allow students to apply what they have learned to actual task performance (Wiggins, 1993). The authentic assessment consists of two components, (1) a task for students to perform, and (2) a rubric by which their performance on the task will be evaluated (Zaim, 2013). Students perform meaningful tasks that replicate a real-world situation based on the tasks given. In a language class activity, teachers determine the tasks that the students will perform to demonstrate their mastery in speaking skills.

Speaking is one of the language skills that have to be mastered by students in learning English. It involves the negotiation of meaning between two or more persons. It is always related to the context in which it occurs. The goal of teaching speaking is to improve students' communicative skills. Language learners need to recognize that speaking involves three areas of knowledge: (1) Mechanics (pronunciation, grammar, and vocabulary): using the right words in the right order with the correct pronunciation. (2) Functions (transaction and interaction): knowing when clarity of message is essential (transaction/ information exchange) and when precise understanding is not required (interaction/ relationship building), and (3) Social and cultural rules and norms (turntaking, rate of speech, length of pauses between speakers, relative roles of participants): Understanding how to take into account who is speaking to whom, in what circumstances, about what, and for what reason.

Assessing speaking is challenging; however, because there are so many factors that influence our impression of how well someone can speak a language. Because we expect the scores to be accurate and appropriate, therefore, a teacher should be able to design and develop an authentic assessment, especially for language learning. The design of authentic assessment suitable with the need of teachers related to language function, activities, and scoring rubrics can be explained as follows.

Table 7

The Design of Authentic Assessment Suitable to the Teachers' Need

\begin{tabular}{|c|c|c|c|}
\hline Basic Competence & Communicative Function & Assessment Activities & Scoring rubrics \\
\hline $\begin{array}{l}\text { Able to arrange } \\
\text { simple oral text in } \\
\text { the form of } \\
\text { interpersonal, } \\
\text { transactional, and } \\
\text { functional text to } \\
\text { communicate with } \\
\text { others. }\end{array}$ & 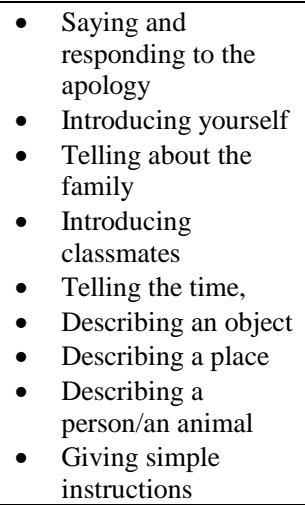 & $\begin{array}{ll}\text { - } & \text { roleplay } \\
\text { - } & \text { act out } \\
\text { - } & \text { pair dialogue } \\
\text { - } & \text { oral interview } \\
\text { - } & \text { picture-cued } \\
& \text { description } \\
\text { - } & \text { story/text retelling } \\
\text { - } & \text { oral report }\end{array}$ & $\begin{array}{ll}\text { - } & \text { Fluency } \\
\text { - } & \text { Pronunciation } \\
\text { - } & \text { Grammar } \\
\text { - } & \text { Vocabulary } \\
\text { - } & \text { Comprehension } \\
\text { - } & \text { Performance } \\
\text { - } & \text { Discourse Feature } \\
\text { - } & \text { Task } \\
& \text { accomplishment }\end{array}$ \\
\hline
\end{tabular}

Based on the design of authentic assessment above, eight models of authentic assessment for speaking skills were developed in order to activate students' ability to 
communicate with others, so that teachers can assess the progress and the achievement of the students in the level of ability needed. Each model was accompanied by the scoring rubrics to indicate the level of achievement of the students. The assessment activities and the scoring rubric needed can be explained as follows.

Roleplay. Role-playing is defined as pretending to be someone else in a specific situation. Roleplay can be done by the students in groups with some activities like greeting/leave-taking, giving and asking information, and also suggesting something. In this case, the key to this model is that students actively make conversation where one delivers a question, and others answer the question. The scoring rubric to measure the students' achievement may have five indicators: task accomplishment, fluency, pronunciation, vocabulary, and grammar.

Act out. Act out means to represent in action, such as students act out what they read. Act out is to express something directly in overt behavior. The scoring rubric that can be used to measure the students' achievement may have three indicators: task accomplishment, comprehension, and pronunciation.

Pair dialogue. We can separate our students in class into pairs. Each pair has a list of questions to ask to his pair. After a student asks the question, the other student must answer with a correct pattern. The teacher can change up the pair partners for each round of questions and answers. The scoring rubric to measure the students' achievement may have five indicators: task accomplishment, fluency, pronunciation, vocabulary, and grammar.

Oral interview. The oral interview is a direct speaking assessment that can be used to assess students' level of speaking proficiency. The teacher and student do a simple interview; the teacher asks the oral question to the students about a topic such as students' background, activities, and students' interests. The scoring rubric to measure the students' achievement may have five indicators: task accomplishment, fluency, pronunciation, vocabulary, and grammar.

Picture-cued description. A picture is a valuable resource as it provides a shared experience in the classroom, a variety of tasks, and a focus of interest for students. Pictures are ideally suited for eliciting oral language from students. Picture-cued provides the students with multiple picture cues. Teachers may ask students to describe, give information, and give the opinion about the picture. The scoring rubric to measure the students' achievement may have four components: fluency, pronunciation, vocabulary, and grammar.

Story/text retelling. Story/text retelling is an activity to encourage students to retell the events that occur in the story/text, which has been read/listened by the students. Student retells main ideas or selected details of text experienced through listening or reading. The scoring rubric to measure the students' achievement may have four components: fluency, pronunciation, vocabulary, and grammar.

Oral report. An oral report is an oral presentation usually done for teachers and classmates. An oral report is an opportunity for students to practice their speaking skills 
in front of the class. Students do an oral presentation about their project that has been done previously. The scoring rubrics to measure students' achievement may have four components: fluency, pronunciation, vocabulary, and grammar.

The assessment activities above require students to perform their language individually and in pairs. Those activities are needed in real-life communication (O'Malley \& Pierce, 1996; Brown \& Abeywickrama, 2010; Rahmawati \& Ertin, 2014, Zaim \& Refnaldi, 2017), and promote speaking skill (Razali \& Isra, 2016). Besides, these assessment activities are also in line with the requirement of the curriculum 2013 (Kemdikbud, 2013). English speaking ability for junior high school requires students to perform simple communication related to the activities near to their environment.

The scoring rubrics are limited to fundamental indicators to measure their speaking skills in producing oral languages such as pronunciation, fluency, grammar, vocabulary, comprehension, and task accomplishment (O'Malley \& Pierce, 1996; Nunan, 1999; Brown \& Abeywickrama, 2010). These four indicators of speaking skill should be paid attention in order to enable students to speak correctly in the language being learned (Pareja, 2015). The scoring rubrics used are holistic rather than analytic since the abilities to be measured limited to specific simple tasks (Zaim \& Amri, 2012).

The speaking assessment activities above present a learning opportunity. Students should be informed before giving an assessment of what and how to assess their speaking ability. By knowing the way how to assess authentically to the learning process, the students will compete to achieve the performance required. Assessment can change the way students learn. A particular type of assessment will motivate students to learn more (Liao, 2015). Schurr (2002) states that authentic assessment is a type of student evaluation that attempts to make the testing process more realistic and relevant. The authentic assessment gives multiple opportunities for students to perform their performance (Choate \& Evans, 1992). This type of assessment is considered a solution that can accommodate students' progress and achievement in the classroom.

Teachers have to develop and use scoring rubrics for each assignment. They can give students a copy of assignment rubrics so that the students can do the assignment well. The scoring rubrics, together with the models of authentic assessment, can be used by teachers in assessing students' speaking skills. In general, the components of scoring rubrics are pronunciation, fluency, vocabulary, grammar, and comprehension. Each component has a description of the level of achievement that possibly achieved by the learners so that the teacher can judge in which level of ability the students are now in the assessment given (Zaim \& Refnaldi, 2016; Sofiana, Mubarok \& Yuliasri, 2019; Adnan, Suwandi, Nurkamto, \& Setiawan, 2019). Clear scoring rubrics will make a subjective measurement to become objective.

An authentic assessment paves the way for direct measurement of students' achievement on tasks through flexible methods (Nasab, 2015). It emphasizes what students know rather than what they do not know, and it requires students to develop responses instead of selecting them from predetermined options (Ojung'a \& Allida, 2017). Besides, authentic assessment is a reliable and valid method of evaluation for assessing speaking 
skills (Finch, 2002). Authentic assessment is a meaningful learning experience with the genuine involvement of the students to carry out a task (Erwing, 1998). Authentic assessments ask students to analyze, synthesize, and apply what they have learned. Teachers decide what students need to be able to do in order to show their mastery of speaking skills (Mueller, 2016). The authentic assessment also contributes to students' attitudes, confidence, and the development of students' language proficiency (Adnan, Suwandi, Nurkamto, \& Setiawan, 2019). Therefore, a model of the authentic assessment development of speaking skills based on teachers' needs and curriculum needs should be implemented at the school.

\section{CONCLUSION}

In this paper, problems and solution for English secondary school teachers in Indonesia have been discussed regarding authentic assessment for speaking skills. The conclusions that can be derived from the findings are as follows. (1) the problems faced by teachers regarding the assessment of certain communicative functions are asking students to say the apology and respond to the apology of others, asking students to introduce themselves, asking students to tell about the family, asking students to introduce classmates, asking students to tell the time, asking students to describe an object, asking students to describe a place, asking students to describe a person/animal, and asking students to give simple instructions. (2) Teachers' needs on the authentic assessment regarding the communicative functions, activities, and scoring rubrics for speaking skills have been found. (3) The model of authentic assessment suitable with teachers' need related to language function, activities, and scoring rubrics have been developed. It can be concluded that the appropriate need analysis can be used effectively in developing an authentic assessment for speaking skills. This study is useful for teachers to assess the speaking skills of their students accurately; and students can benefit from realizing their real ability and in which skills they need to improve. The limitation of this research is that using a self-perception survey for teachers might have led to biased results.

\section{ACKNOWLEDGMENTS}

We want to express our sincere appreciation to the teachers and students participants who have involved in this research. This research was funded by the Ministry of Research, Technology, and Higher Education, Indonesia.

\section{REFERENCES}

Adnan, Suwandi, S., Nurkamto, J., \& Setiawan, B. (2019). Teacher competence in authentic and integrative assessment in Indonesian language learning. International Journal of Instruction, 12(1), 701-716. https://doi.org/10.29333/iji.2019.12145a

Bachman, L.F. (1990). Fundamental consideration in language testing. Oxford: Oxford University Press.

Brown, H, D., \& Abeywickrama, P. (2010). Language assessment principles and classroom practices. New York: Pearson Education, Inc

Choate, S. J., \& Evans, S. S. (1992). Authentic assessment of special learner: Problem and promise. Education Journal Northeast Louisiana University. 
Erwing, S. C. (1998). Alternative assessment: Popularity, pitfalls, and potential. Assessment Update, 10, 1-12.

Finch, A. E. (2002). Authentic assessment: Implications for EFL performance testing in Korea. Secondary Education Research, 49, 89-22.

Haryono, A. (2009). Authentic assessment dan pembelajaran inovatif dalam pengembangan kemampuan siswa. JPE. 2(1), 1-12.

Imran, S. (2009). Authentic assessment. Retrieved from http://ipankreview.wordpress. com /2--9/03/22/authentic_assessment/.

Irwana, E. (2006). Penerapan asesmen otentik dalam pembelajaran bahasa Indonesia; Studi kasus di SMPN 1 Wlingi, Kecamatan Wlingi, Kabupaten Blitar. Skripsi. Fakultas Sastra, Universitas Negeri Malang.

Kemdikbud. (2013). Peraturan menteri pendidikan dan kebudayaan no. 81a tentang implementasi kurikulum 2013. Jakarta: Kementerian Pendidikan dan Kebudayaan.

Knight, B. (1992). Assessing speaking skills: A workshop for teacher development. ELT Journal, 46(3), 294-302.

Kurniasih, I., \& Sani, B. 2014. Implementasi kurikulum 2013: Konsep dan penerapan. Surabaya: Kata Pena

Lazim, M. (2013). Penerapan pendekatan saintifik dalam pembelajaran kurikulum 2013. Retrieved from http://eprints.uny.ac.id/i0777/1/P\%20-\%2054.pdf.

Liao, H.C. (2015). EFL learner perceptions of differentiated speaking assessment tasks. English Teaching and Learning, 39(1), 29-68.

Moon T. R. (2005). Development of authentic assessments for the middle school classroom, The Journal of Secondary Gifted Education. 16(2/3).

Mueller, J. (2016). What is authentic assessment? Retrieved from http://jfmueller.faculty. noctrl.edu/toolbox/whatisit.htm.

Nasab, F.G. (2015). Alternative versus traditional assessment. Journal of Applied Linguistics and Language Research, 2(6), 165-178.

Navidinia, H., Mobaraki, M., \& Malekzadeh, F. (2019). Investigating the effect of noticing on EFL students' speaking accuracy. International Journal of Instruction, 12(1), 83-98. https://doi.org/10.29333/iji.2019.1216a.

Nurgiantoro, B. \& Suyata, P. (2009). Pengembangan model asesmen otentik dalam pembelajaran bahasa. Cakrawala Pendidikan, 28(3), 224-237

Ojung'a \& Allida, D. (2017). A survey of authentic assessments used to evaluate English language learning in Nandi Central Sub-County Secondary School, Kenya. Baraton Interdisciplinary Research Journal, 7, 1-11.

O’Malley, J. M., \& Pierce, L. V. (1996). Authentic assessment for English language learning: Practical approaches for teachers. New York: Addison-Wesley Publishing.

Pareja, T. P. (2015). Language needs assessment of selected Filipino learners in second language classrooms. International Journal of Arts \& Sciences, 8(2), 479-492. 
Rahmawati, Y., \& Ertin. (2014). Developing assessment for speaking. Indonesian J of English Education (IJEE), 1(2), 200-209. https://doi.org/10.15408/ijee. v1i2.1345.

Razali, K., \& Isra, M. (2016). Male and female teachers' roles in assessment of speaking skills. Gender Equality: International Journal of Child and Gender Studies, 2(1), 1-10.

Rukmini, D \& Saputri, L.A.D.E (2017). The authentic assessment to measure students' English productive skills based on 2013 curriculum. Indonesian Journal of Applied Linguistics, 7(2), 263-273.

Sahyoni, \& Zaim, M. (2017). Authentic assessment of speaking skills for grade 1 Junior High School. Komposisi: Jurnal Pendidikan Bahasa Sastra dan Seni, 18(1), 15-26.

Sofiana, N., Mubarok, H., \& Yuliasri, I. (2019). English language teaching in secondary school: An analysis of the implementation of Indonesian ELT 2013 curriculum. Int Journal of Instruction, 12(1), 1533-1544. https://doi.org/10.29333/iji.2019.12198a.

Schurr, L. S. (2002). Authentic assessment: Professional reference for teacher. Journal of Teaching at Middle School.

Taufina. (2009). Authentic assessment dalam pembelajaran bahasa Indonesia di kelas rendah SD. PEDAGOGI: Jurnal Ilmiah Ilmu Pendidikan, 9(1), 113-120.

Warmbrod, J. R. (2014). Reporting and interpreting scores derived from Likert-type scale. Journal of Agricultural Education, 55(5), 30-47. doi: 10.5032/jae.2014.05030.

Whitelock, D., \& Cross, S. (2012). Authentic assessment: What does it mean, and how is it instantiated by a group of distance learning academics? Int $J$ of e-Asses 2(1), 1-10.

William, D. (2016). What are the advantages of authentic assessment over standardized testing? Retrieved from http://oureverydaylife.com/advantages_authentic_assessment_ over_standardized_testing_20187.html.

Wiggins, G. (1993). A true test: Toward more authentic and equitable assessment. Phi Delta Kappan

Wu, J. R. W. (2014). Investigating Taiwanese teachers' language testing and assessment need. Eng. Teaching and Learning, 38(1), 1-27. dx.doi.org/10.6330/ ETL.2014.38.1.01.

Zaim, M., \& Amri, Z. (2012). Implementasi authentic assessment dalam pembelajaran bahasa Inggris SMPN RSBI Kota Padang. Padang: FBS UNP

Zaim, M. (2013). Asesmen otentik: Implementasi dan permasalahannya dalam pembelajaran bahasa Inggris di sekolah menengah. Proceeding International Seminar on Languages and Arts. Padang: FBS UNP Press.

Zaim, M., \& Refnaldi. (2016). Teachers' need for authentic assessment of speaking skills. Proceeding International Seminar on Languages and Arts (ISLA) 5. Padang: FBS UNP Press.

Zaim, M. (2017). Implementing scientific approach to teach English at senior high school in Indonesia. Asi. Soc Sci, 13(2), 33-40. http://dx.doi.org/10.5539/ ass.v13n2p33. 